\title{
Vertical tectonics of the High Plateau region, Manihiki Plateau, Western Pacific, from seismic stratigraphy
}

\author{
Huirong-Anita Ai · Joann M. Stock • \\ Robert Clayton · Bruce Luyendyk
}

Received: 2 May 2006/ Accepted: 19 January 2008/Published online: 27 February 2008

(C) The Author(s) 2008

\begin{abstract}
The Manihiki Plateau is an elevated oceanic volcanic plateau that was formed mostly in Early Cretaceous time by hotspot activity. We analyze new seismic reflection data acquired on cruise KIWI 12 over the High Plateau region in the southeast of the plateau, to look for direct evidence of the location of the heat source and the timing of uplift, subsidence and faulting. These data are correlated with previous seismic reflection lines from cruise CATO 3, and with the results at DSDP Site 317 at the northern edge of the High Plateau. Seven key reflectors are identified from the seismic reflection profiles and the resulting isopach maps show local variations in thickness in the southeastern part of the High Plateau, suggesting a subsidence (cooling) event in this region during Late Cretaceous and up to Early Eocene time. We model this as a hotspot, active and centered on the High Plateau area during Early Cretaceous time in a near-ridge environment. The basement and Early Cretaceous volcaniclastic layers were formed by subaerial and shallow-water eruption due to the volcanic activity. After that, the plateau experienced erosion. The cessation of hotspot activity and subsequent
\end{abstract}

\footnotetext{
H.-A. Ai · J. M. Stock $(\bowtie) \cdot$ R. Clayton

Division of Geological and Planetary Sciences, California

Institute of Technology, Pasadena, CA 91125, USA

e-mail: jstock@gps.caltech.edu

H.-A. Ai

e-mail: huirong.ai@gmail.com

R. Clayton

e-mail: clay@gps.caltech.edu

B. Luyendyk

Department of Geological Sciences, University of California,

Santa Barbara, CA, USA

e-mail: luyendyk@geol.ucsb.edu
}

heat loss by Late Cretaceous time caused the plateau to subside rapidly. The eastern and southern portions of the High Plateau were rifted away following the cessation of hot spot activity. As the southeastern portion of the High Plateau was originally higher and above the calcium carbonate compensation depth, it accumulated more sediments than the surrounding plateau regions. Apparently coeval with the rapid subsidence of the plateau are normal faults found at the SE edge of the plateau. Since Early Eocene time, the plateau subsided to its present depth without significant deformation.

Keywords Cretaceous · Hotspot - Isopach map · Manihiki Plateau $\cdot$ Seismic reflection

\section{Introduction and tectonic background}

The Manihiki Plateau is an area of elevated ocean floor in the Western Pacific Ocean. The water depth of the plateau is at approximately $2.5-3 \mathrm{~km}$, several kilometers shallower than the surrounding oceanic basins (Fig. 1). Winterer et al. (1974) divided the Manihiki Plateau into three regions. The High Plateau, in the southeastern section of the Manihiki Plateau, is the shallowest and flattest, with water depths of $2.5-3.0 \mathrm{~km}$ (Fig. 1). Up to $1 \mathrm{~km}$ of pelagic sedimentary rock covers the igneous basement. The High Plateau is bordered by linear depressions thought to be fault troughs (Winterer et al. 1974). The Western Plateaus comprise smaller ridges and seamounts northwest of the High Plateau. The North Plateau is a small and nearly separate shallow plateau at the northern end of the region.

The edges of the High Plateau are steep and linear along the southwest, east and northwest, where the plateau has borders with surrounding basins (Fig. 1). The shallowest 
Fig. 1 Bathymetric map of Manihiki Plateau. Bathymetry is from the GEBCO digital atlas published by the British Oceanographic Data Centre on behalf of IOC and IHO, 1997. Much of this bathymetry is the same as in Winterer et al. (1974). Inset is topography from satellite altimetry (Smith and Sandwell 1997)

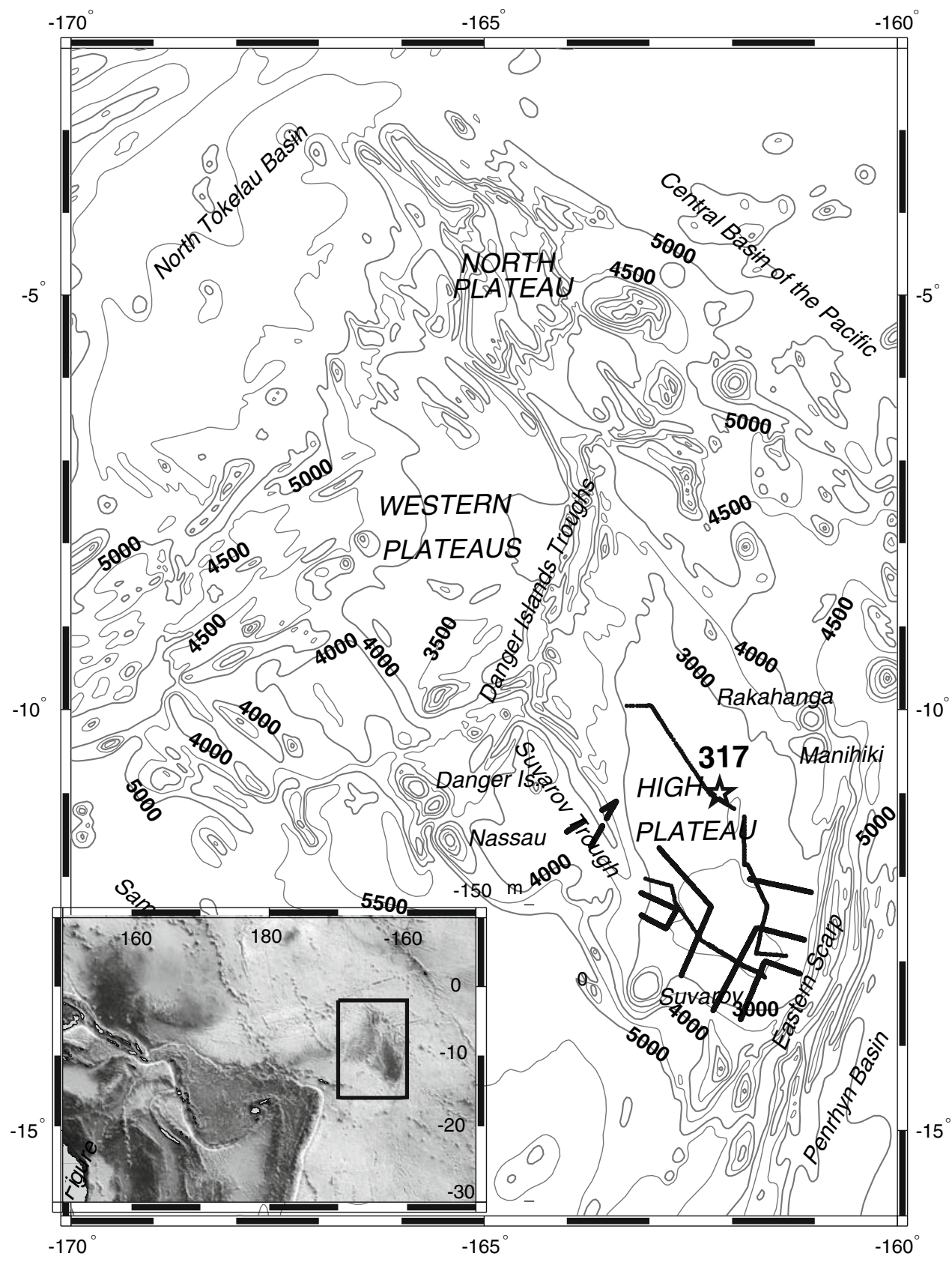

and most consistently steep edge, on the east, is defined by the Eastern Scarp, which bounds a linear, relatively flattopped ridge trending NNE that is 500-600 m higher than the adjacent High Plateau. This is the easternmost of a set of parallel structures that separate the High Plateau from the Penryhn Basin $3 \mathrm{~km}$ below. It is part of the longer Manihiki Scarp that borders the entire plateau on the eastern side (Larson et al. 2002). Towards the southwest of its center, the High Plateau gradually deepens. The southwestern edge of the High Plateau is bounded by the Suvarov Trough. This feature is a simple asymmetric graben that separates the High Plateau from a deeper plateau province (the Nassau Plateau). Along this boundary, there is no adjacent high standing ridge such as that seen along the Eastern Scarp. There is some evidence of longwavelength folds lower on the Nassau Plateau near the Samoan Basin. It is suggested that the Nassau Plateau is deformed by gravity tectonics of Late Cretaceous or Early Cenozoic age, and that the Suvarov Trough is a break-away structure (Stock et al. 1998).

Originally it was thought that the High Plateau is a subsided micro-continent (Heezen et al. 1966). It is now accepted that the Manihiki Plateau is anomalously thick oceanic crust, based on the results of Deep Sea Drilling Project (DSDP) Site 317 on the plateau (Winterer et al. 1974; Schlanger et al. 1976). The formation of the 
Manihiki Plateau was related to Early Cretaceous intense volcanism and/or ridge jumping in the vicinity of major transform offsets. Winterer et al. (1974) believed that the formation of the Manihiki Plateau was tectonically related to a large jump in the ridge-ridge-ridge (RRR) triple junction from the Nova-Canton Trough to a location south of the Manihiki Plateau. Lonsdale (1997) proposed that the Manihiki Plateau rifted from the conjugate Hikurangi Plateau, now adjacent to and east of New Zealand, in Early Cretaceous time. This rift might be the same as that discussed in Sutherland and Hollis (2001), who suggested a Cretaceous spreading ridge south of the Pacific-Phoenix Ridge at the Gondwana margin. They also suggested that material accreted from the oblique subduction of the Moa plate is now part of the Eastern province of New Zealand. Larson et al. (2002) proposed that during 121-119 Ma the triple junction originated at the northwest corner of the original Manihiki Plateau, which was then about twice its present size. The plateau was subsequently rifted into three fragments, two of which were rafted away (Stock et al. 1998; Larson et al. 2002). Based on new seafloor fabric data, Taylor (2006) proposed that Ontong Java-ManihikiHikurangi Plateau was once the single largest oceanic plateau that has since separated into its various parts.

Geochemical and petrologic analysis of the basement basalts that have been recovered at DSDP Site 317 confirms that the Manihiki Plateau has the composition of oceanic crust. In major element composition, these basement basalts are of MORB-like tholeiitic type (Schlanger et al. 1976). Mahoney and Spencer (1991) measured the isotopic ratios of $\mathrm{Pb}, \mathrm{Nd}$ and $\mathrm{Sr}$ for the basalts of the Manihiki Plateau and found that most of the samples have relatively low ${ }^{206} \mathrm{~Pb} /{ }^{204} \mathrm{~Pb}$, high ${ }^{208} \mathrm{~Pb} /{ }^{204} \mathrm{~Pb}$, and moderate ${ }^{87} \mathrm{Sr} /{ }^{86} \mathrm{Sr}$ indicative of mantle sources. They concluded that the sources of the basalts fall well within the modern-day oceanic island or hotspot field. Beiersdorf et al. (1995) surveyed volcanic rocks covering a high seamount NE of DSDP Site 317, at the eastern edge of the Manihiki Plateau, just SW of Rakahanga Atoll. Their work confirmed the results of Mahoney and Spencer (1991), indicating a hotspot involvement during the formation of the plateau basement. Additional analyses of these and other Manihiki Plateau samples by Ingle et al. (2007) show that several distinct mantle sources were involved.

Ito and Clift (1998) considered the Manihiki Plateau to be a Large Igneous Province (LIP) and investigated the sedimentary record of DSDP Site 317 on the plateau to determine the thermal subsidence history. They concluded that the thermal subsidence history of the plateau was comparable to that of normal seafloor, but less than that predicted by thermal models of hotspot-affected lithosphere. They explained this by invoking late stage underplating and proposed that the formation of the
Manihiki Plateau was related to a hotspot. The more recent analysis by Clift (2005) argues that the subsidence is less than typical for normal oceanic lithosphere, similar to that reconstructed for the Ontong-Java Plateau.

Prior to coring operations at DSDP Site 317, several single-channel seismic reflection lines were collected over the plateau during expedition CATO 3 (Winterer et al. 1974). Considerable research has been done on samples from DSDP Site 317 in terms of paleontology, geochemistry, lithology, etc, as well as analysis of the seismic reflection data of CATO 3 to constrain the evolution history of the Manihiki Plateau. The present model for the tectonic evolution of the Manihiki Plateau is based on either the low resolution single channel seismic reflection data collected three decades ago (Winterer et al. 1974), or simply geochemical and paleontological analysis from the DSDP drilling sites (e.g. Schlanger et al. 1976; Ito and Clift 1998). However, the coverage of CATO3 lines is limited and no attempt has been made to correlate the drilling results with the seismic reflection data across the whole plateau. Furthermore, reconstruction of a subsidence history of the Manihiki Plateau based on DSDP Site 317 samples may not represent the evolution of this whole region since the drilling site is in a basement depression. Our regional seismic grid allows us to examine the lateral variation of seismic facies and thus assess possible variations in subsidence across the region.

In this paper, we augment the data of Winterer et al. (1974) by adding new single channel seismic reflection data and correlate these with previously available seismic data and DSDP drilling results to constrain the tectonic subsidence history of the Manihiki Plateau. The study region in this paper is confined to the High Plateau. To assess the lateral variability of the stratigraphy of the Manihiki Plateau, we have constructed isopach maps from the available seismic reflection data and have established a more detailed subsidence history model, which shows the High Plateau has subsided more than adjoining regions.

\section{Data and methods}

About 4,000 km of single channel seismic reflection, SeaBeam swath bathymetry and magnetic field data were acquired in May 1998 over the High Plateau and surrounding ocean regions as part of the KIWI 12 cruise on the R/V Roger Revelle (Stock et al. 1998). The seismic reflection survey utilized two 210 cubic inch air guns. For regular profiling both guns used a firing interval of $10 \mathrm{~s}$. The recording length of regular profiles was $7 \mathrm{~s}$. The average trace interval spacing was $45 \mathrm{~m}$.

The new KIWI 12 seismic reflection data are analyzed and correlated with the 1972 CATO 3 seismic lines and 


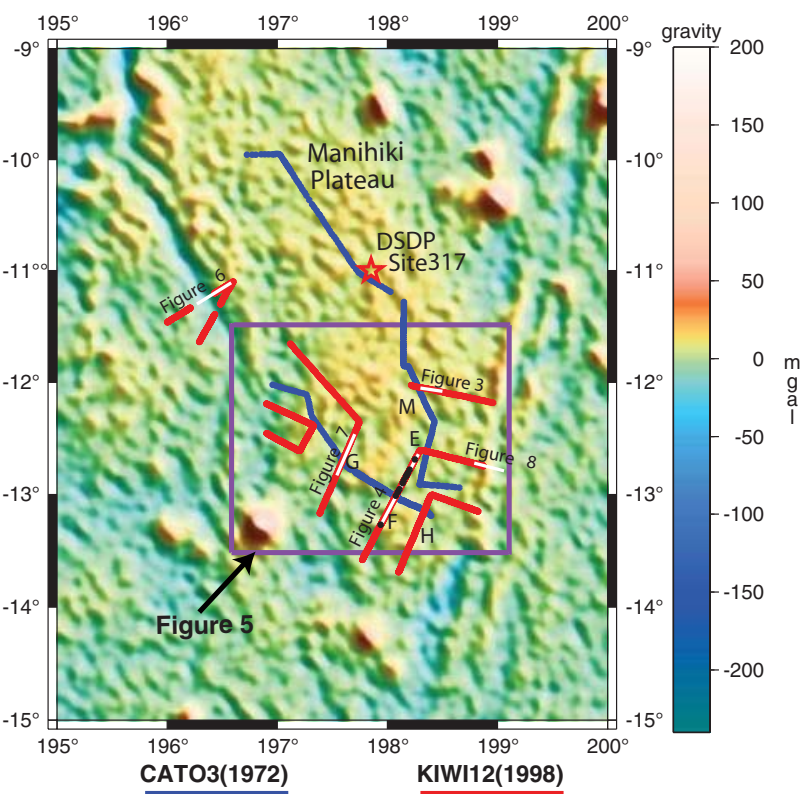

Fig. 2 Map of High Plateau showing seismic reflection lines discussed in this paper, and Sandwell and Smith (1997) satellite gravity field. Blue lines are CATO 3 collected in 1972; red lines are KIWI 12 collected in 1998; star is DSDP Site 317, located at $11^{\circ} \mathrm{S}$, $162^{\circ} 15^{\prime} \mathrm{W}$; points E, F, G, H are tie points of KIWI 12 and CATO 3 lines. White lines on top of KIWI 12 are locations of seismic profiles in Figs. 3, 4, 6, 7 and 8. Black points on line of Fig. 4 are where faults are picked. Black square is location for Fig. 5

with the drilling and seismic results from DSDP Site 317 (Schlanger et al. 1976) (Fig. 2). DSDP Site 317 is located on a CATO 3 seismic line, so its stratigraphy can be correlated directly with the reflection profiles. At DSDP Site 317, seven seismic units and two major unconformities U1 (Early/Late Eocene) and U2 (Late Cretaceous/Early Eocene) were biostratigraphically dated and tied to the CATO 3 seismic reflection profiles (Schlanger et al. 1976). The new KIWI 12 tracks are tied to the existing CATO 3 tracks at three of four crossing points in the study area shown in Fig. 2. The seismic reflection profiles of the Glomar Challenger, CATO 3, and the new data, KIWI 12, are correlated with the section drilled at DSDP Site 317 (Fig. 3). Based on the drilling results (Schlanger et al. 1976), three lithologic Mega-Sequences with seven units were identified, which are bounded in the profiles by seven reflectors Q-R1 through eC-R7, from seafloor down to the basement (Table 1). Figure 4 is an example of the reflectors picked from one of the KIWI 12 seismic profiles.

This study depends on how well the new seismic reflection profiles are correlated with the old seismic reflection profiles and with DSDP Site 317. The travel times of the major reflectors correlate well at tie points $\mathrm{E}, \mathrm{F}$ and $\mathrm{G}$ between the KIWI 12 and CATO 3 lines (Table 2). At other crossing points on the High Plateau no clear reflectors are visible, either because of proximity to the edge of the High Plateau, or else because the resolution of the earlier seismic data, CATO3, is poor.

The seven stratigraphic reflectors were then used to construct isopach maps (in Two-Way-Travel-Time) of layer thickness and depth below sea surface for each reflector. These are discussed in detail in the next section.

\section{Discussion of isopach mapping}

Previous constraints on stratigraphy and lithology

The lithologic units penetrated in DSDP Site 317 include $910 \mathrm{~m}$ of sedimentary rocks and $34 \mathrm{~m}$ of underlying basaltic basement (Schlanger et al. 1976). The sedimentary rocks are divided into three stratigraphic Mega-Sequences bounded by unconformities. Mega-Sequence 1, which is above reflector eE-R5 (U1), is upper Eocene through recent oozes and chalks; Mega-Sequence 2 is lower Eocene cherty chalk, underlain by a large unsampled section, and bounded by reflectors eE-R5 (U1) and 1C-R6; MegaSequence 3 is largely Maestrichthian ( $\sim 67 \mathrm{Ma})$ to Aptian $(\sim 120 \mathrm{Ma})$ limestone and volcaniclastic sedimentary rocks, bounded by reflectors 1C-R6 and eC-R7 (Table 1, Fig. 3). U2 lies at or slightly above reflector 1C-R6. In DSDP Hole 317A, the upper part of the volcaniclastic section lies below the top of the L. cabri zone which is dated at $120 \mathrm{Ma}$ (Erba 2004). Geochemical, sedimentological, and paleontological analysis of the volcaniclastic strata and uppermost basement rocks from DSDP Site 317 shows that they were originally deposited in a shallower water environment than at present depth, about $200 \mathrm{~m}$ (Schlanger et al. 1976; Jenkyns 1976).

The top of the basalt basement is represented by Reflector eC-R7. ${ }^{40} \mathrm{Ar} /{ }^{39} \mathrm{Ar}$ dating of the basalt from DSDP Site 317 indicated that the basalts were erupted around $123.7 \pm 1.5 \mathrm{Ma}$ (Mahoney et al. 1993; Larson and Erba 1999). The vesicular character of the basalts also indicates that the eruptions took place in shallow water (Schlanger et al. 1976).

The seven reflectors and isopach maps

The seven reflectors are correlated across the entire High Plateau region on the KIWI 12 and CATO 3 data. Reflector $\mathrm{eC}-\mathrm{R} 7$ is the deepest reflector identifiable and is interpreted as the top of the basalt basement. It is traceable across most of the High Plateau. The $0.6 \mathrm{~s}$ two-way-travel-time (TWT) reflector 1C-R6 is suggested to represent either sediment in Core 33-317-4, the change from Maestrichthian chalk ( $\sim 67 \mathrm{Ma})$ to fairly hard Campanian claystone ( $75 \mathrm{Ma})$ around $70 \mathrm{Ma}$, or the hiatus between Core 33-317-6 and Core 33-317-7, around $89 \mathrm{Ma}$, where a major lithologic 


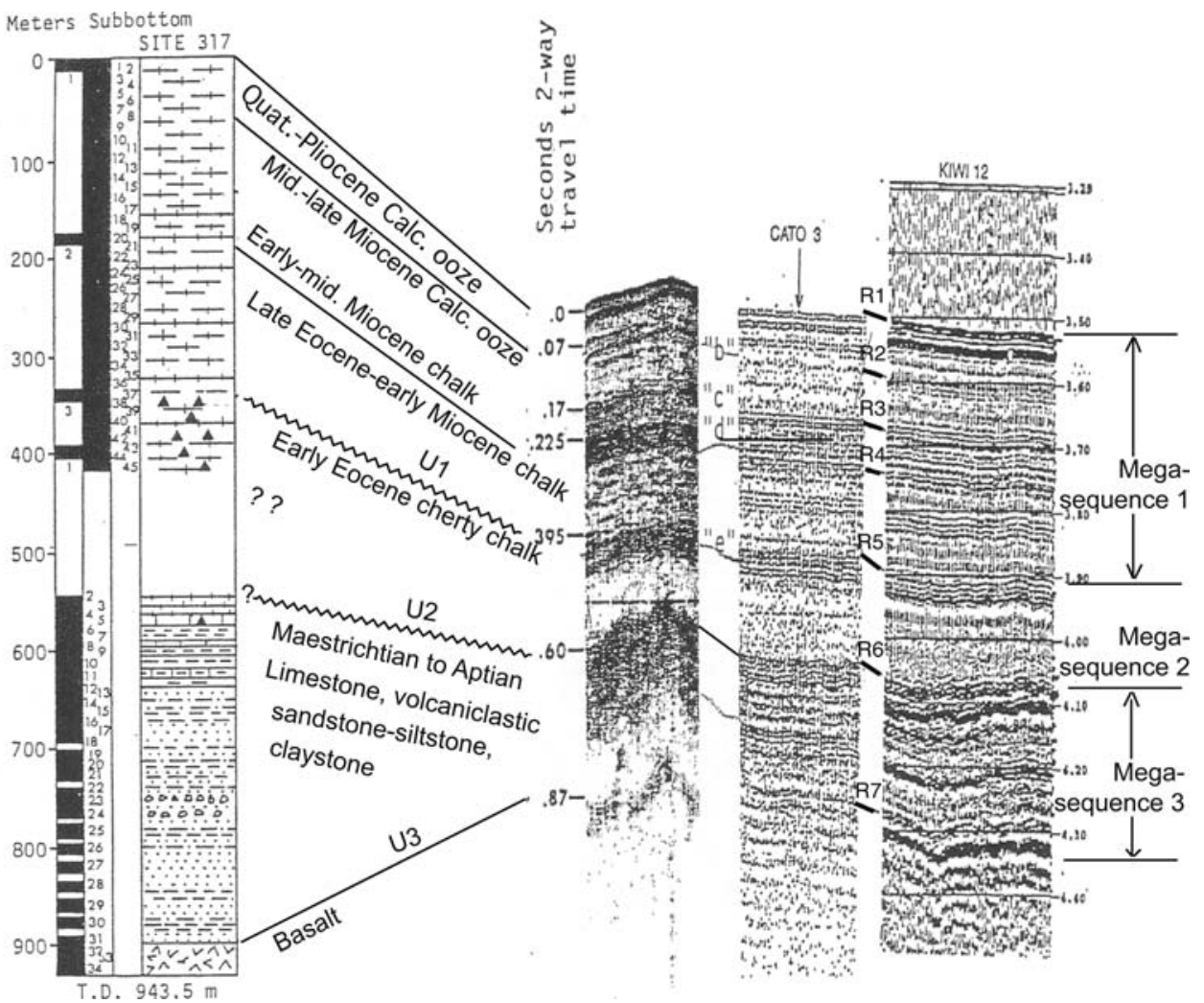

Fig. 3 Correlation between DSDP Site 317, CATO 3 seismic reflection profile and reflectors Q-R1 to eC-R7 on KIWI 12, new seismic reflection results. Location of KIWI line shown in Fig. 2. Stratigraphy of DSDP Site 317 and its correlation with CATO 3 is from Schlanger et al. (1976). Lower case letters "b," "c," "d," and "e" identified by Schlanger et al. (1976) are correlative with 0.07 , $0.17,0.225$, and $0.395 \mathrm{~s}$ reflectors, respectively; these are reflectors IM-R2, mM-R3, mM-R4 and eE-R5 according to our definition.

change is present (Schlanger et al. 1976). This reflector is at or slightly below unconformity U2. No previous work has given a clear interpretation for this unconformity. For convenience, reflector 1C-R6 and unconformity U2 are grouped together for the rest of this paper. The lower part of the MegaSequence beneath reflector 1C-R6 is traceable across our whole study area, indicating that the eruption and subsequent reworking produced widespread volcaniclastic deposits across the whole High Plateau. The continuity of the U1 unconformity reflector is good but not as strong as U2. It is associated with an unconformity in the Middle Eocene rocks. Reflectors 1M-R2 through eE-R5 are sub-parallel to the seafloor, and have only slight regional changes of subbottom time, indicating a relatively stable sedimentary history since Early Eocene time. These reflectors are weak compared to reflectors $1 \mathrm{C}-\mathrm{R} 6$ and $\mathrm{eC}-\mathrm{R} 7$, and sometimes unidentifiable on the seismic reflection profiles.

Representative Two-Way-Travel-Time contours and time-isopach maps using the digitized seismic reflection profiles were made for the region south of $11.5^{\circ} \mathrm{S}$, where there is adequate seismic coverage (Fig. 5). On these
Reflectors we identify (Table 2) have abbreviated labels R1 to R7 in this figure. Stratigraphic ranges of Mega-Sequences 1, 2 and 3 are also marked in plot (see text). Left side of plot, from Schlanger et al. (1976), shows in black the depths from which cores were taken in the three holes at this site. Uppermost cores 1, 2, and 3 (leftmost column) are from hole 317 ; core 1 at $400 \mathrm{~m}$ depth, and cores 2-34 (shown in black in left column) are from hole 317A; cores 1-45 (2nd column, black continuous region) are from hole $317 \mathrm{~B}$

contour and isopach maps we can see many of the important features of the sedimentary Mega-Sequences. Reflectors Q-R1 to eE-R5, Mega-Sequence 1 (above U1) comprising Upper Eocene chalk to Quaternary calcareous ooze, are very flat in the region bounded by $197^{\circ}$ to $198.5^{\circ} \mathrm{E}, 12^{\circ}$ to $13^{\circ} \mathrm{S}$ on the High Plateau (Fig. 5a). The flat character of reflectors Q-R1 to eE-R5 is interpreted to result from a relatively stable evolution history of the Manihiki Plateau since Early Eocene time. The time isopach maps of the layers bounded by reflectors Q-R1 through eE-R5 in the same small region are relatively constant except towards the edge of the High Plateau (Fig. 5d). This uniformity shows that the Manihiki Plateau mainly experienced sedimentation, and possible subsidence, as a whole since Early Eocene time. In contrast, the Two-Way-Travel-Time contour map of reflector 1C-R6 (U2), above the sedimentary and volcaniclastic rocks, has a different pattern from that of the reflectors Q-R1 to eE-R5 (Fig. 5b). In Fig. 5b, the topography for the same region is more undulating than it is on maps of reflectors Q-R1 through eE-R5. The contours have two high points; one 


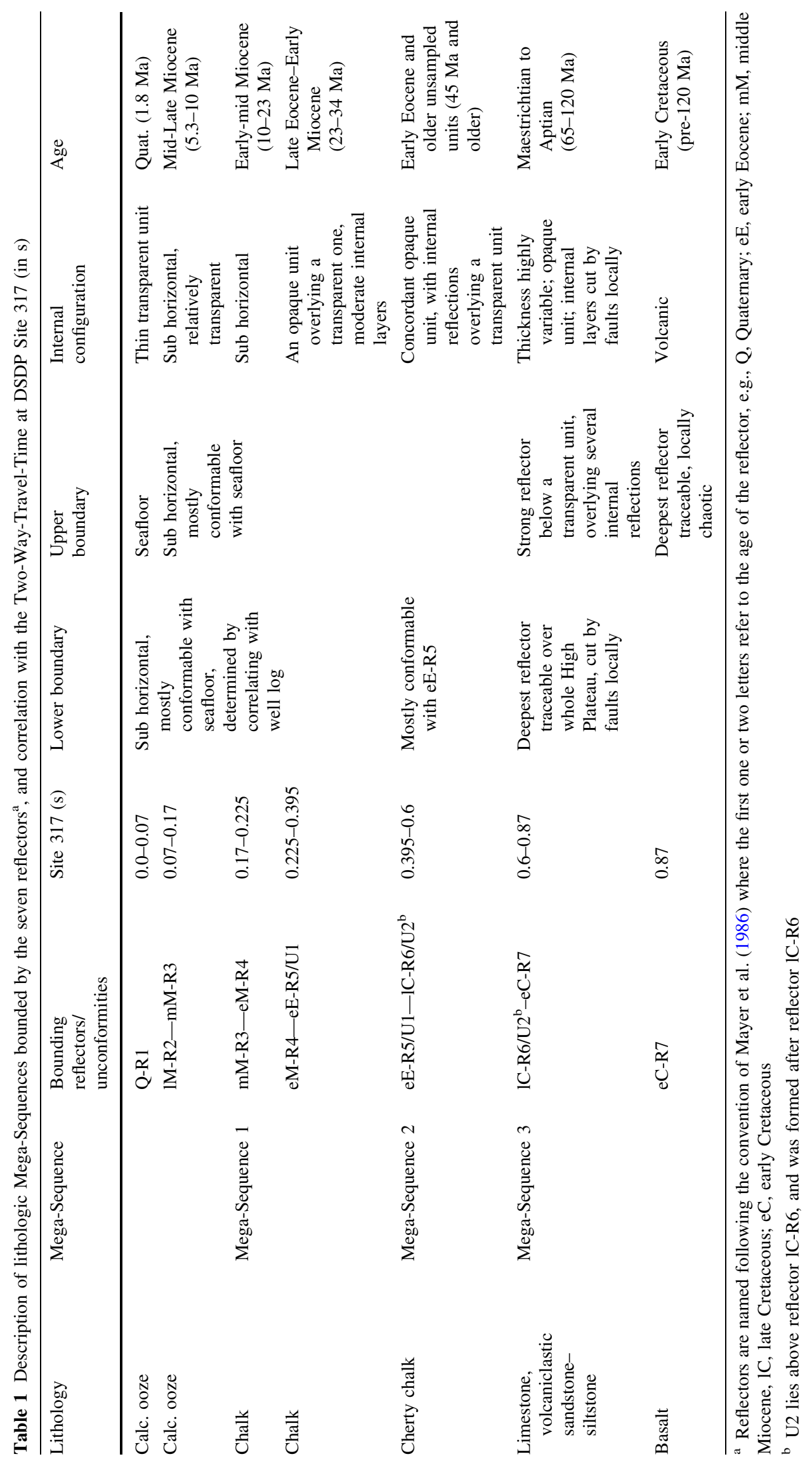




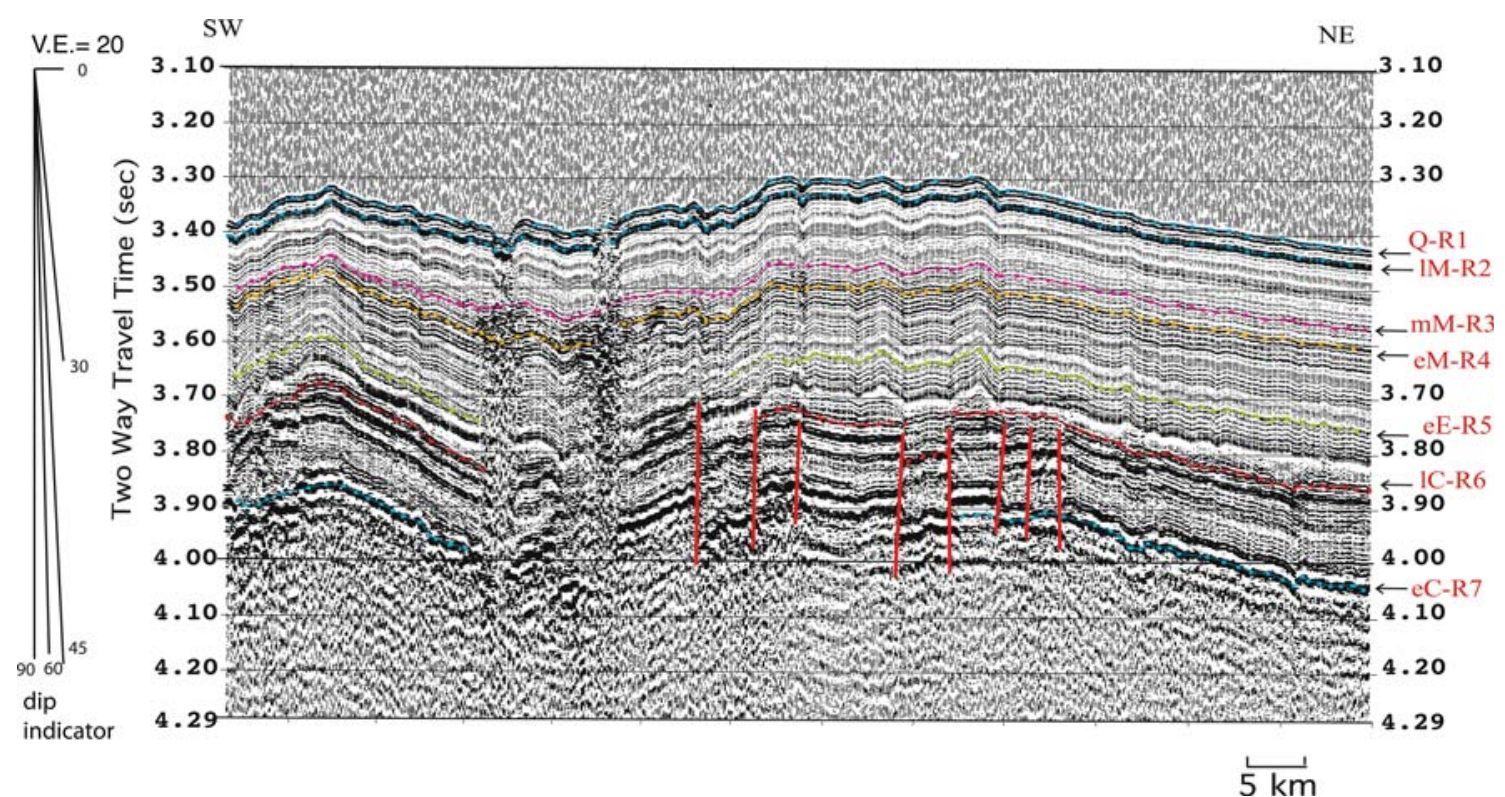

Fig. 4 Seismic profile from KIWI 12, showing identified reflectors Q-R1 to eC-R7. Location of line is shown in Fig. 2. The 1C-R6 and eC-R7 reflectors are affected by normal faults (picked as thick red lines). Vertical exaggeration is about 20:1. Seafloor relief correlates to faults due to draping of Mega-sequences 1 and 2 over fault-controlled relief. Spherical divergence correction and $20-240 \mathrm{~Hz}$ band pass filter have been applied

Table 2 Comparison of Two-Way-Travel-Time (in s) at the tie points (E, F and G) between the CATO 3 and KIWI 12 seismic reflection lines

\begin{tabular}{lllll}
\hline Reflectors & E & F & G & M \\
& $\begin{array}{l}\text { CATO3/KIWI12 } \\
\left(161.65^{\circ} \mathrm{W}, 12.65^{\circ} \mathrm{S}\right)\end{array}$ & $\begin{array}{l}\text { CATO3/KIWI12 } \\
\left(161.91^{\circ} \mathrm{W}, 13.34^{\circ} \mathrm{S}\right)\end{array}$ & $\begin{array}{l}\text { CATO3/KIWI12 } \\
\left(162.39^{\circ} \mathrm{W}, 12.78^{\circ} \mathrm{S}\right)\end{array}$ & $\begin{array}{l}\text { CATO3/KIWI12 } \\
\left(162.2^{\circ} \mathrm{W}, 12.1^{\circ} \mathrm{S}\right)\end{array}$ \\
\hline Q-R1 & $0.00 / 0.00$ & $0.00 / 0.00$ & $0.00 / 0.00$ & $0.0 / 0.0$ \\
lM-R2 & $0.05 / 0.06$ & $0.04 / 0.06$ & $0.05 / 0.05$ & $0.07 / 0.09$ \\
mM-R3 & $0.14 / 0.15$ & $0.16 / 0.18$ & $0.12 / 0.14$ & $0.17 / 0.18$ \\
mM-R4 & $0.18 / 0.21$ & $0.23 / 0.27$ & $0.24 / 0.20$ & $0.225 / 0.25$ \\
eE-R5 & $0.33 / 0.35$ & & $0.36 / 0.36$ & $0.395 / 0.42$ \\
lC-R6 & $0.39 / 0.40$ & $0.38 / 0.38$ & $0.43 / 0.44$ & $0.6 / 0.64$ \\
eC-R7 & n.a./0.54 & $0.57 / 0.58$ & $0.68 / 0.68$ & $0.87 / 0.87$ \\
\hline
\end{tabular}

near $197.8^{\circ} \mathrm{E}, 12.9^{\circ} \mathrm{S}$, and the other to the northwest, at $197.2^{\circ} \mathrm{E}, 12.2^{\circ} \mathrm{S}$. Between the two high regions there is a depression, where the Two-Way-Travel-Time exceeds $3.8 \mathrm{~s}$.

In the same region, the isopach map of Mega-Sequence 2 , bounded by reflectors $1 \mathrm{C}-\mathrm{R} 6$ and eE-R5, is different from that between reflectors Q-R1 and eE-R5 (Fig. 5d vs. e). Thickness of this unit varies from 0.1 to $0.3 \mathrm{~s}$ (Fig. 5e). This difference in thickness suggests that the Manihiki Plateau was influenced by tectonic events prior to reflector 1C-R6 time.

The basement surface of the High Plateau (reflector eC-R7) exhibits significant relief, similar to reflector 1C-R6 (Fig. 5c). This has important implications for the paleowater depth history. At DSDP Site 317, the paleodepth near the top of the volcaniclastic section $(200 \mathrm{~m}$ above the basement at this site) was about $100 \mathrm{~m}$, as judged from the molluscan fauna in recovered cores (Kaufmann 1976). However, DSDP Site 317 was deliberately drilled in a basement depression, which was evident on the site survey seismic lines (Schlanger and Winterer 1976). These seismic profiles, as well as our results, suggest that over much of the High Plateau, and particularly to the SE of DSDP Site 317 , the top of the basement is more than $100 \mathrm{~m}$ shallower than the volcaniclastic strata drilled at DSDP Site 317. If this basement is the same age or older than the basement at DSDP Site 317, and if there has not been much subsequent tilting, it is possible that a considerable portion of the High Plateau would have been subaerial during or shortly after its formation. This would provide a likely location for subaerial erosion to have contributed to the volcaniclastic sedimentary rocks inferred to be present 


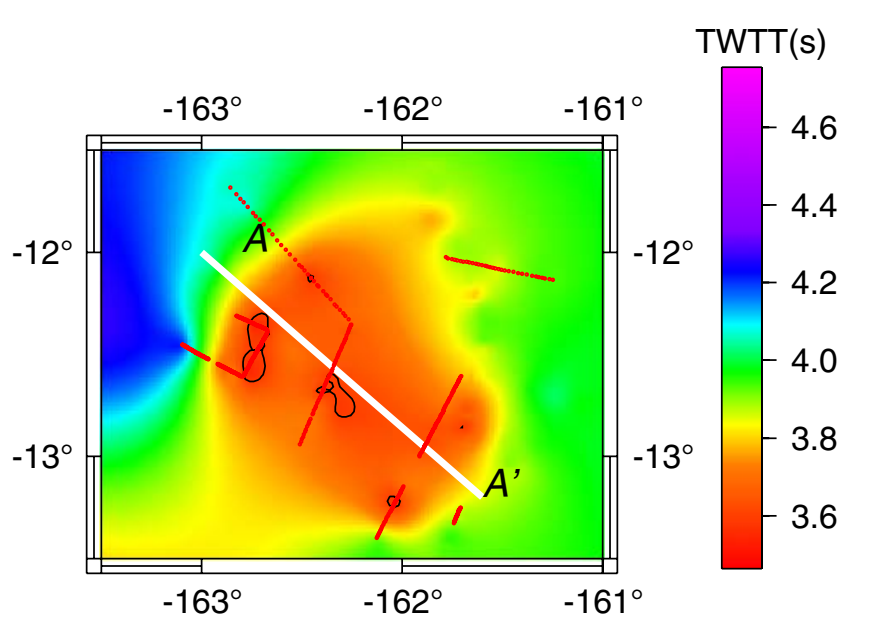

(a) Depth of R5
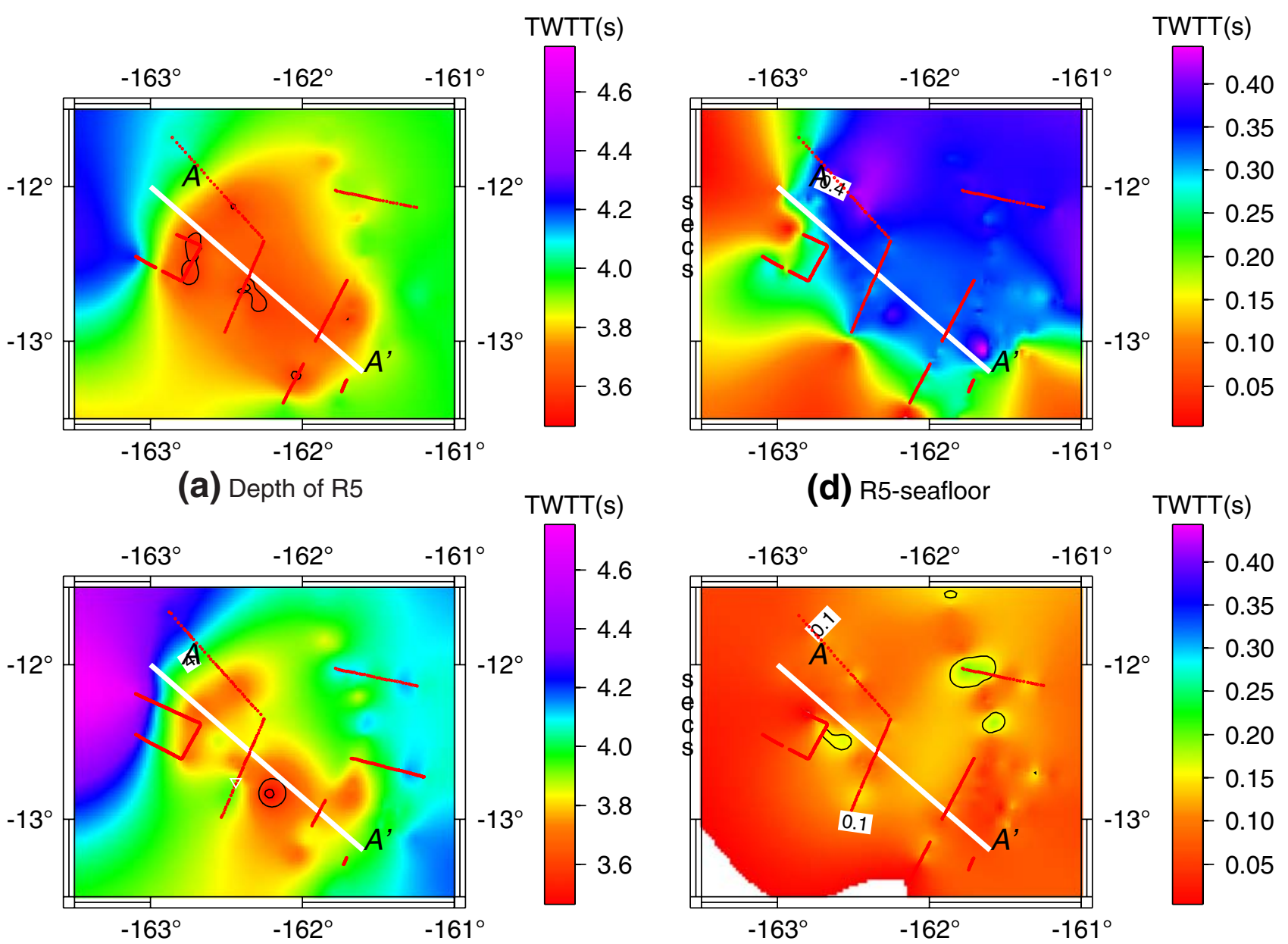

TWTT(s)

(d) R5-seafloor

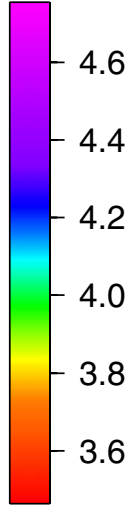

(b) Depth of R6

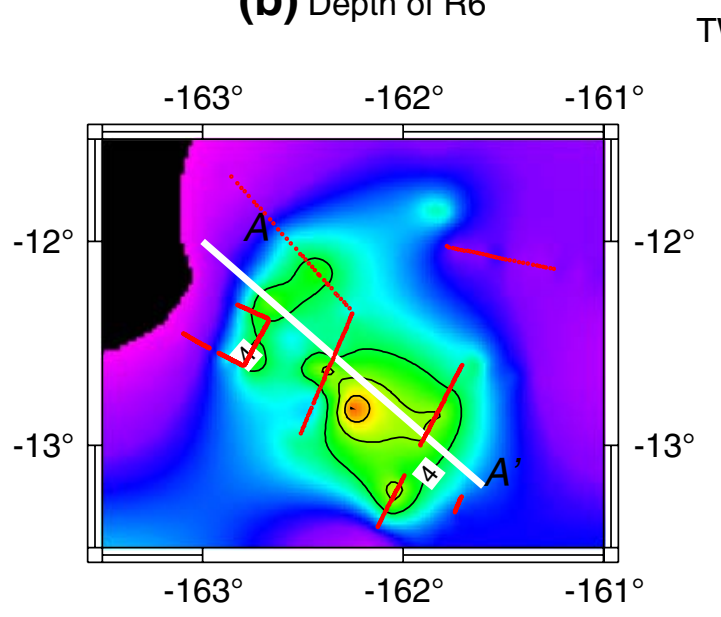

(c) Depth of R7

TWTT(s)

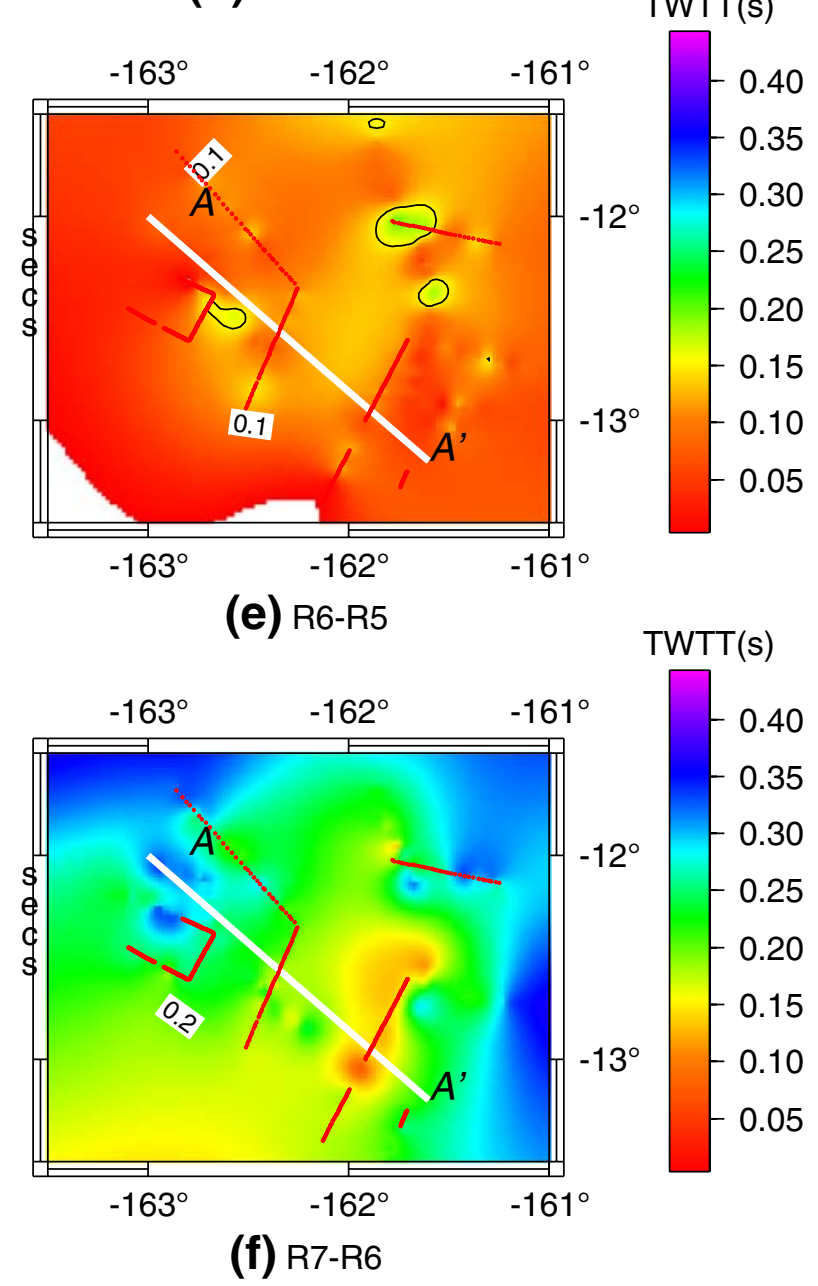

TWTT(s)

bounded by reflectors eE-R5 and Q-R1; (e) Time-isopach map of thickness of layer bounded by reflectors 1C-R6 and eE-R5; (f) Timeisopach map of thickness of layer bounded by reflectors eC-R7 and 1C-R6 
Fig. 6 Western rim near Suvarov Trough. Locations are shown in Fig. 2. No spherical divergence correction, Bandpass filter same as Fig. 4
Fig. 7 Southwestern edge showing disturbed High Plateau relief. Others same as Fig. 6. See Fig. 2 for location
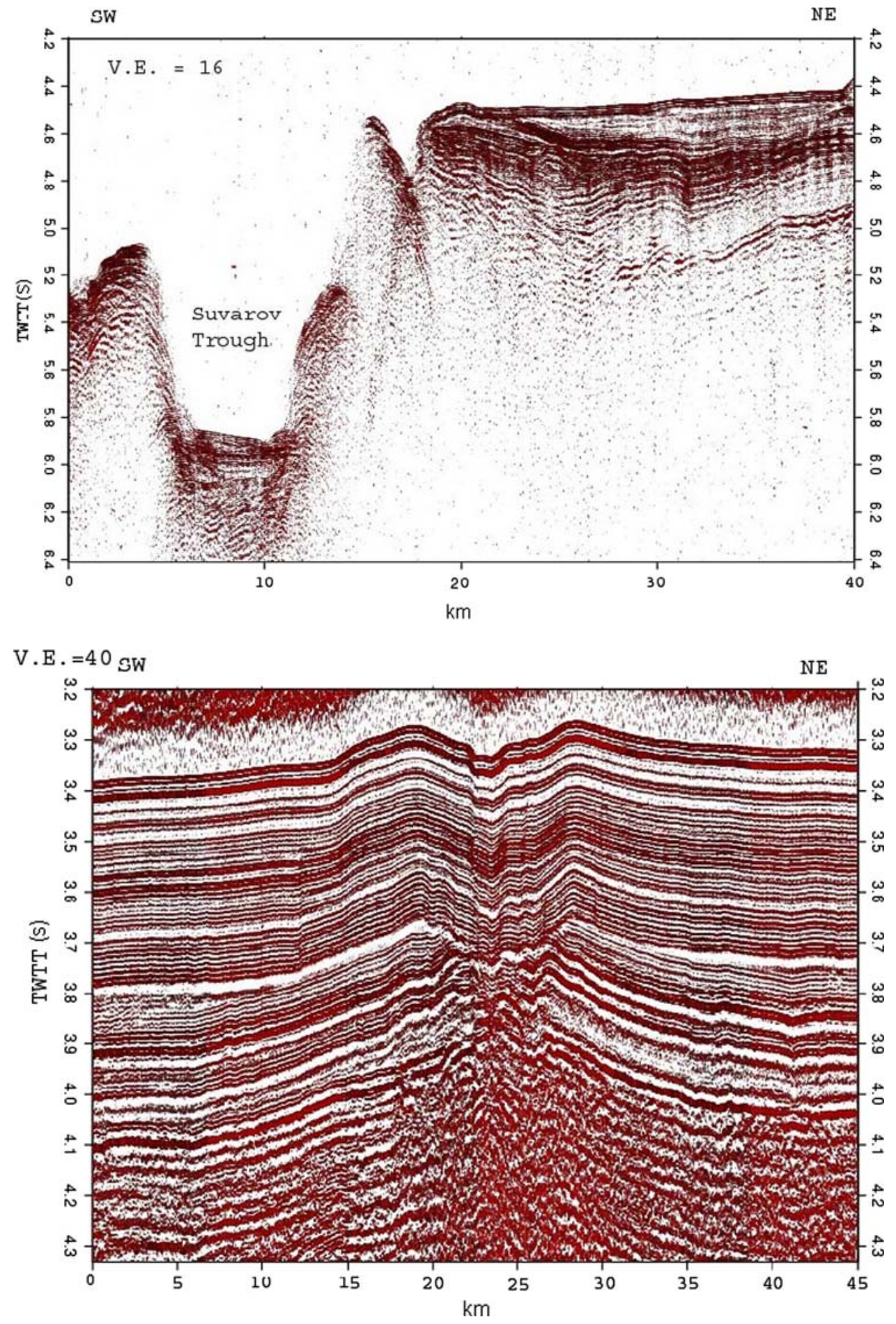

throughout the plateau, above reflector eC-R7 (Winterer et al. 1974). In addition to volcaniclastic material produced in subaerial eruptions, some of the volcaniclastic strata could be epiclastic material derived from subaerial basement highs. This would provide a plausible explanation for the otherwise puzzling occurrence of a considerable percentage of rounded grains in the volcaniclastic sandstones in DSDP Site 317 (noted by Jenkyns 1976).
Boundaries of the high plateau

Tilted volcaniclastic beds are observed on the western rim of the High Plateau, near the Suvarov Trough. The upper Tertiary sedimentary layers are relatively flat (Fig. 6). Seismic profiles indicate that the sediment deposited in Suvarov Trough is about $200 \mathrm{~m}$ thick (Fig. 6). Whether these sediments were formed by primary deposition or by 
Fig. 8 KIWI 12 Seismic reflection profile records of Eastern Scarp, High Plateau of Manihiki Plateau

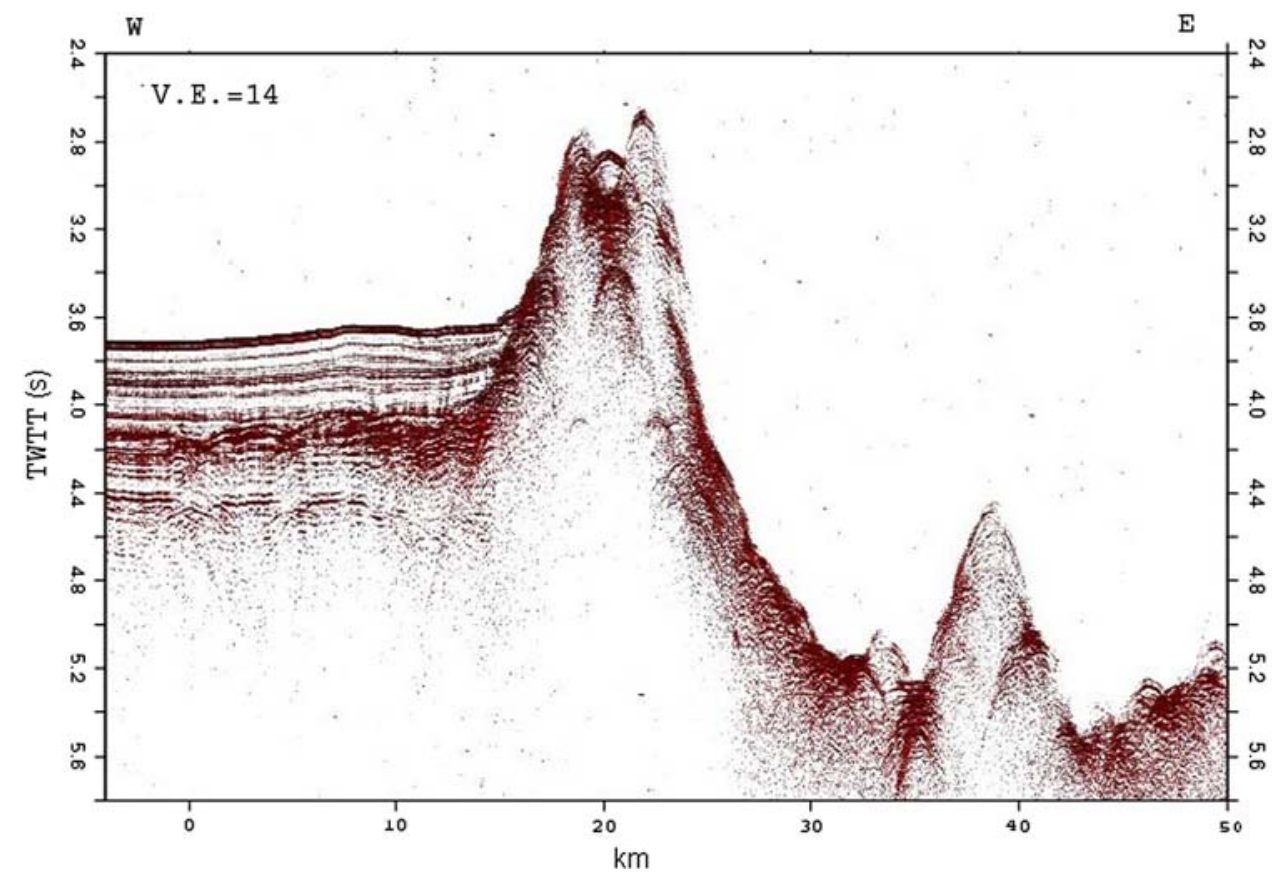

slumping of the sediments from the High Plateau is not clear from the profile.

Deeply buried basement highs are clearly visible in seismic reflection profiles from both the CATO 3 and KIWI 12 cruises. The reflectors Q-R1 through eE-R5 are draped over the previously disturbed High Plateau relief (e.g. Fig. 7). This basement high identified on the profiles is near the southwestern edge of the High Plateau (see Fig. 2).

At the eastern edge of the High Plateau, the NNEtrending Eastern Scarp comprises a zone (100 km wide) of four to five parallel linear ridges and basins each with a relief of 500-2,000 m. This ridge and trough region continues south and north of the High Plateau where it is named the Manihiki Scarp. Stock et al. (1998) interpret this feature as a transtensional dextral fracture zone formed during a change in spreading direction in Late Cretaceous time. The eastern part of the High Plateau appears truncated with an adjacent block possibly sheared off and transported away from the High Plateau (Fig. 8). As seen in Fig. 8, younger sediments are displaced upward, suggesting that the Eastern Scarp was active after these younger sediments were deposited. On the three crossings of the Eastern Scarp on the KIWI 12 cruise, as well as on one crossing obtained on the NBP0304 cruise, multibeam bathymetric data show that between $12^{\circ} 15^{\prime} \mathrm{S}$ and $13^{\circ} 15^{\prime} \mathrm{S}$ this elevated basement rim has a consistent, and relatively flat top, at a depth of about 2,100 m (Fig. 9). It is possible, therefore, that this linear ridge was extruded and/or uplifted when the High Plateau was at a depth of about $700 \mathrm{~m}$. In this case the linear ridge may have then been eroded to sea level, after which it would have experienced $2,100 \mathrm{~m}$ of subsidence to bring it down to the depth at which it is found today.

There are significant normal faults throughout and along the margins of the High Plateau, cutting seismic reflectors. For instance, Fig. 4 shows faults displacing reflector eC-R7, the top of the basement, and the $1 \mathrm{C}-\mathrm{R} 6$ reflector, the top of the volcaniclastic layer. The faults do not affect the U2 unconformity. One possible explanation for the origin of these faults is strain associated with the cooling of the plateau, after the volcanism stopped. Another explanation is regional rifting, as explained next.

Joseph et al. (1993) reported faults striking NW-SE on the northeast and southwest edges of the Manihiki Plateau. Joseph et al. (1993) related the faults to the mid-Cretaceous reorganization of the Pacific-Farallon-Phoenix ridgeridge-ridge (RRR) triple junction (PAC-FAR-PHN). Larson et al. (2002) also related the faulting of the Manihiki Plateau to the tectonic evolution of this RRR triple junction, and proposed that the Manihiki Plateau was broken and lost two pieces that have drifted away: one piece to the NE (on the Farallon plate) and one to the southeast (rifted from the Eastern Scarp onto the Phoenix plate). An additional piece containing the Hikurangi Plateau rifted away to the south (Lonsdale 1997; Billen and Stock 2000). Therefore, the widespread normal faults throughout and along the margins of the High Plateau were probably the joint result of younger post-volcanic cooling and the earlier evolution of the triple junction with breakup of the original Manihiki Plateau.

Very few minor faults cut the upper Cenozoic sedimentary layers, and they are confined to steep escarpments, 


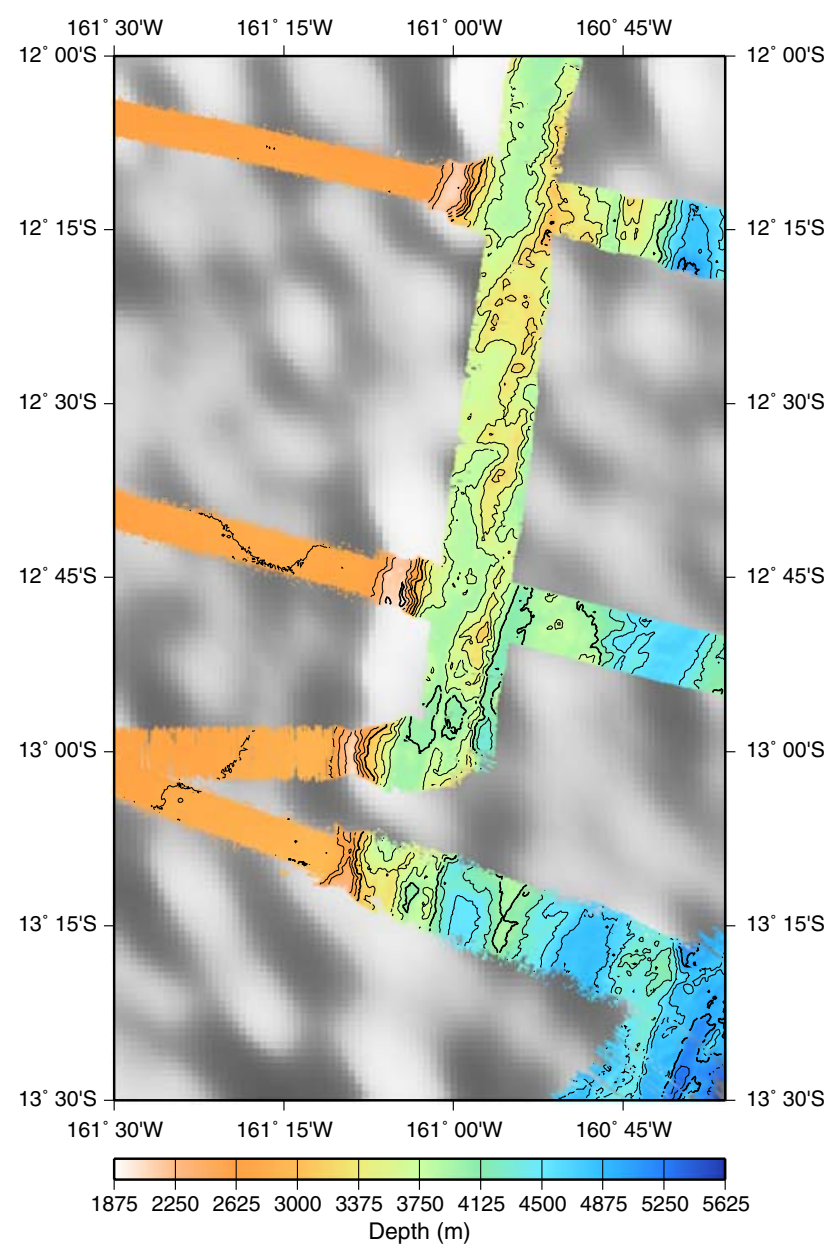

Fig. 9 Bathymetric contour map of SeaBeam data from KIWI 12 and Simrad EM120 data from NBP0304 showing the relatively flat character of the high ridge along the Eastern Scarp of the Manihiki Plateau

such as the western edge. These faults may be caused by slumping near the edge of the plateau and provide little evidence for the whole tectonic evolution history of the plateau.

\section{Model for Manihiki Plateau evolution}

The schematic cross-section shown in Fig. 10d is derived from the maps of Fig. 5a-f. As discussed previously, the Q-R1 through eE-R5 (U1) reflectors are relatively flat, while the IC-R6 and eC-R7 reflectors show more relief. Normal faults cut through the eC-R7 and 1C-R6 reflectors, but do not affect unconformity $\mathrm{U} 2$ and the section above it.

As a model to explain the formation of the Manihiki Plateau, we propose that during Early Cretaceous time, the plateau began to form due to volcanism from a mantle hotspot, ultimately reaching shallow depths. The presence of a hotspot is suggested by the isotopic analysis for basalts (a) $\sim 120 \mathrm{Ma}$

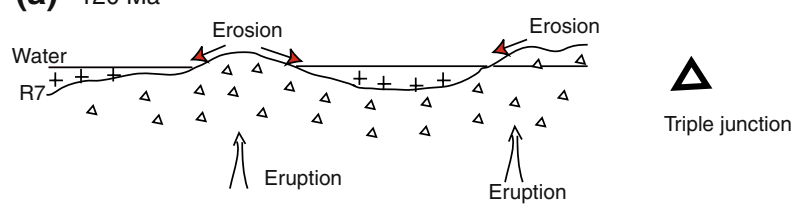

(b) 120 118 Ma

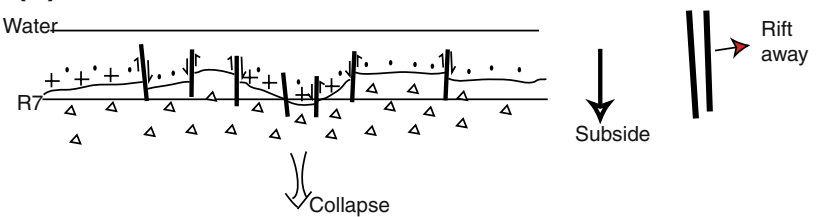

(c) $118 \sim 89$ (?) $\mathrm{Ma}$

Water

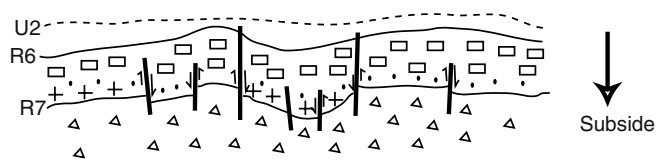

(d) $89(?)$ Ma-present

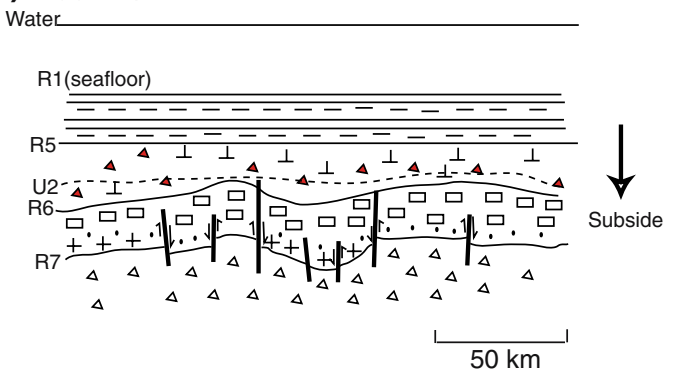

Fig. 10 Schematic sketch showing evolution of High Plateau region of Manihiki Plateau based on cross-section $\mathrm{AA}^{\prime}$ in Fig. 5. Vertical axis (not to scale) is exaggerated for clarity. (a) During Early Cretaceous time $(\sim 120 \mathrm{Ma})$, plateau was partly above sea level due to activity of a hotspot. Basalt basement and volcanic edifices were formed by eruption. Volcaniclastic sedimentary layers were deposited by erosion of subaerial basement. Original plateau might have been near a triple junction; (b) 120-118 Ma: hotspot activity died away and plateau began to experience cooling and subsidence, as evidenced by the change in marine fauna. Calcareous sediments were deposited overlying volcaniclastic layers. During this time, original plateau might have been separated and rifted away. Normal faults were formed either from contraction during cooling, or from separation and rifting of plateau; (c) 118-89(?) Ma: Deposition of calcareous sediments continued; formation of reflector 1C-R6. Faults cut through eC-R7 and 1C-R6 reflectors. Plateau continued subsiding; Unconformity $\mathrm{U} 2$ is probably formed during this time; (d) Since Early Eocene time, plateau subsided to its present depth

of the plateau done by Mahoney and Spencer (1991) and Beiersdorf et al. (1995), who noted that basalts of the Manihiki Plateau fall well within the category of oceanic island or near-ridge hotspots. By $120 \mathrm{Ma}$, the activity of the hotspot had created the basement of the original Manihiki Plateau, and formed the top of the basement. The uppermost basement basalts at DSDP Site 317 were erupted in shallow water, while the region of the southeast High Plateau was shallower and could have been subaerial. 
The ancient RRR triple junction would originally have been northeast of our study area (Larson et al. 2002). The suggested formation near a RRR triple junction is comparable with the evolution history of Shatsky Rise, located northwest of the Manihiki Plateau (Ito and Clift 1998). Volcaniclastic sedimentary layers were deposited on top of the basement as erosion progressed. A considerable percentage of grains were rounded during this erosion and transportation (Fig. 10a). The deposition of the volcaniclastic sediments was widespread throughout the plateau, suggesting that the volcanic source regions were also widespread.

The short-lived volcanism died away after $118 \mathrm{Ma}$. Subsequent lithospheric cooling caused the Manihiki Plateau to subside. Calcareous sediments began to be deposited at this time (Fig. 10b). The "shallow-shelf" character of the volcaniclastic sedimentary rocks, in contrast with the deep water sedimentary rocks overlying the volcaniclastic rocks, indicates rapid sinking of the plateau at this time. Several bathymetric depressions were formed by the rapid subsidence of the plateau. Possibly coeval with the subsidence are the normal faults that cut through reflector eC-R7 and the overlying volcaniclastic layers. It seems likely that these normal faults were, at least in part, formed during the rapid subsidence of the plateau following the end of hotspot activity. The original plateau, which might have been a very large subaerial volcanic province, was separated. One section rifted away to the south (the present Hikurangi Plateau). Another section rifted away to the east and is now missing. Deposition of limestone and cherts continued from 118 to $\sim 89 \mathrm{Ma}$ when reflector 1C-R6 was formed (Fig. 10c). The undulating geometry of reflector 1C-R6 is the result of either irregular basement topography, or lateral variation in cooling rates.

Since the location of reflector 1C-R6, and/or the unconformity $\mathrm{U} 2$, is not well defined from the present drill hole data, there is no reliable explanation for its formation and age. One possibility is given by Schlanger et al. (1976), who postulated based on analysis of foraminifera in the sedimentary rocks that an uplift event happened at the Santonian-Turonian $(\sim 89 \mathrm{Ma})$ boundary to form the reflector 1C-R6. Although uplift of the plateau is consistent with the paleontological data, it is difficult to explain the driving force for this uplift. Winterer et al. (1974) suggested that this unconformity was formed after Paleocene time, but this seems to be ruled out by the results of DSDP Site 317.

Since Early Eocene time or earlier (starting somewhere within the sampling gap from 411 to $554 \mathrm{~m}$ at DSDP Site 317 ), thick layers of pelagic sediments were deposited on the top of the Manihiki Plateau (Fig. 10d). Foraminifera are very scarce in the clay-rich cherty chalk of the Lower Eocene, referred to as Mega-Sequence 2 in this work
(Jenkyns 1976). The foraminiferal content and $\mathrm{CaCO}_{3}$ concentrations are known to be indices of carbonate dissolution, and the lack of foraminifera suggests a shallow calcite compensation depth (CCD), which is related to the productivity and dissolution rate of $\mathrm{CaCO}_{3}$ in the ocean. $\mathrm{A}$ shallow calcite compensation depth is consistent with results from ODP leg 199 to the east, which showed that the CCD near the equator was shallower than $3,300 \mathrm{~m}$ in the Paleocene and Eocene, with a sudden deepening to ca. $4,500 \mathrm{~m}$ at the Eocene/Oligocene boundary (Rea and Lyle 2005). A deepening of the CCD by ca. $1 \mathrm{~km}$ at this time is found in various other ocean basins, suggesting a global oceanographic event (Rea and Lyle 2005).

Mega-Sequence 1, the Late Eocene to Recent oozes and chalks, bounded by reflectors Q-R1 and eE-R5, is characterized by dominantly calcareous strata with carbonate contents greater than $90 \%$, consistent with deposition above the CCD. Unconformity U1, between MegaSequences 1 and 2, may be due to submarine erosion (Jenkyns 1976). It is older than the global deepening of the CCD that occurred near the Eocene/Oligocene boundary; however, more drill hole studies in this part of the SW Pacific are needed to establish its significance. The smooth pattern of the time-isopach maps of reflectors Q-R1 through eE-R5 indicates little tectonic activity since Late Eocene time (Fig. 10d).

\section{Discussion}

Our results allow us to revisit the conclusions of Ito and Clift (1998) concerning the history of the Manihiki Plateau. Ito and Clift (1998) constructed a subsidence curve for the Manihiki Plateau based on the results of DSDP Site 317. Our study connects the seismic stratigraphy of this hole to the region to the southeast, the High Plateau. Although, as Ito and Clift (1998) summarize, DSDP Site 317 may not have been subaerial, considerable portions of the plateau to the southeast may have been near or above the sea surface, judging from the basement relief visible in the seismic sections. This provides a likely explanation for the common occurrence of rounded grains in the sandstones drilled in the volcaniclastic section at DSDP Site 317.

The plate tectonic model of Larson et al. (2002) and Taylor (2006) would allow for the possibility that the plateau was originally much larger. In this scenario, very large pieces of the plateau rifted off to the east (now subducted?) and to the south to form the Hikurangi Plateau as suggested by Lonsdale (1997). In such a case, modeling of the load due to the hotspot volcanism and the predicted subsidence is more complicated, because the original load could have included a much larger mass than what presently comprises the Manihiki Plateau. This was not 
envisioned in the subsidence calculations of Ito and Clift (1998). Areas that are now rafted away could have provided a much more extensive source of subaerial weathering of the volcanic edifices, to produce the thick volcaniclastic section preserved above the basement in the High Plateau.

Recent observations of the Hikurangi Plateau adjacent and east of New Zealand (Hoernle et al. 2004) are also relevant to the interpretation of the Manihiki Plateau area, because of the proposed original connection between the two plateaus prior to rifting along the seafloor spreading system that formed the Osbourn Trough (Lonsdale 1997; Billen and Stock 2000). On the basis of swath bathymetry and other underway geophysical data from the Hikurangi Plateau, Hoernle et al. (2004) identify several major stages of volcanism in its history: first, overall plateau growth; second, late-stage isolated volcanic cones; third, intrusions along normal faults that accommodated the separation of the Hikurangi Plateau from the Manihiki Plateau. Their model requires the surface of the Hikurangi Plateau to subside from near sea level to about 1,500 m water depth before the eruption of the late-stage volcanoes, and prior to the separation of the Hikurangi and Manihiki Plateaus. Hoernle et al. model would suggest that the Manihiki and Hikurangi Plateaus would have been adjacent to one another until after the 1,500 $\mathrm{m}$ of subsidence had occurred.

In our study area on the High Plateau of the Manihiki Plateau, we do not see evidence for late stage seamounts of the type identified by Hoernle et al. (2004) on the Hikurangi Plateau. However, we only have swath bathymetry coverage along our track lines, which cover a very limited area of the High Plateau. We identify basement highs along some of the steep bathymetric scarps on the Eastern Scarp and the Suvarov Trough (Fig. 10). There are also some low-relief highs within the plateau interior, which are now nearly buried by the Tertiary sedimentary rocks. These highs consist of unstratified, most likely igneous, material, and in some cases we cannot rule out the possibility that these represent a later stage of volcanism than that which formed the major part of the plateau. The high ridge along the Eastern Scarp could have formed by magmatism along a marginal fault system, similar to the suggested origin of Hoernle et al. (2004) for some of the ridges on the Hikurangi Plateau. Its roughly flat-topped character, if due to erosion at sea level, would require it to have been emplaced after the main plateau had already sunk to depths in excess of $700 \mathrm{~m}$. At the eastern edge of the High Plateau, conical seamounts such as Mt. Eddie and Rakahanga Atoll were surveyed and sampled. Petrography and geochemistry analysis of the basement samples suggest subaerial volcanic origin, and isotopic dating shows that age of these seamounts is in accord with the formation of the Manihiki Plateau (Beiersdorf et al. 1995).
We do not see a straightforward way to reconcile the models of Larson et al. (2002) and Hoernle et al. (2004) in terms of the timing of separation of the three hypothetical former plateau fragments. Larson et al. (2002) suggest that the Eastern Scarp rifted at $\sim 119 \mathrm{Ma}$, but Hoernle et al. model would require somewhat later timing for the separation between the Manihiki and Hikurangi Plateaus because the plateaus would have to subside to $\sim 1,500 \mathrm{~m}$ water depth prior to separation. In this case, one might expect a continuation of the Eastern Scarp to be present on the east side of the Hikurangi Plateau, but no such scarp is visible in existing bathymetric data.

There is currently no precise constraint on the time of separation of the Manihiki and Hikurangi plateaus because the intervening seafloor formed by the Osbourn Trough spreading system appears to have been all formed during the Cretaceous Normal Superchron (120-84 Ma) and lacks magnetic reversal isochrons. To have the Manihiki-Hikurangi rifting be later than $119 \mathrm{Ma}$ would not violate the marine geophysical data. However, to invoke diachronous rifting of the various plateau segments leads to geometrical complications in the implied triple junction configurations in the region.

\section{Conclusions}

Seven seismic reflectors are traced across the southeastern part of the High Plateau region of the Manihiki Plateau. Isopach maps of the time thickness of layers bounded by pairs of reflectors indicate unequal thinning and thickening during Early to Late Cretaceous time in the studied area. In contrast, the thickness of layers bounded by reflectors formed since Early Eocene time is relatively constant in the same region. A model to explain this observation is that a thermally elevated plateau rapidly subsided when the hotspot died away during Early Cretaceous time. Differential subsidence caused the local thickening observed in the isopach maps and may be related to the extensive set of normal faults cutting through the basement and the Lower Cretaceous volcanic sedimentary rocks found at the southeast edge of this area. The activity of the hotspot was in a near-ridge environment during the formation of the original Manihiki Plateau. The Eastern, or Manihiki, Scarp is related to the rearrangement of the PAC-FAR-PHN triple junction near the Manihiki Plateau around 121119 Ma (Stock et al. 1998; Larson et al. 2002) and marks where a piece of the High Plateau rifted away. The plateau began to subside to its present depth after Early Cretaceous and before Early Eocene time. The relatively constant pattern of sediment deposition since Early Eocene time indicates that the plateau experienced little tectonic evolution except thermal subsidence since then. 
Acknowledgments We thank Patricia Persaud for her insightful discussion and numerous suggestions. We also thank graduate and undergraduate students from Caltech and UC Santa Barbara for their assistance on KIWI 12. Research supported by University of California San Diego, Scripps Institution of Oceanography, UC Santa Barbara, and Caltech. Nathaniel B. Palmer multibeam data collection was supported by NSF OPP-0126334. Contribution 8945, Division of Geological and Planetary Sciences, California Institute of Technology. Contribution of the Institute for Crustal Studies, University of California, Santa Barbara, number 0810.

Open Access This article is distributed under the terms of the Creative Commons Attribution Noncommercial License which permits any noncommercial use, distribution, and reproduction in any medium, provided the original author(s) and source are credited.

\section{References}

Beiersdorf H, Bach W, Duncan R, Erzinger J, Weiss W (1995) New evidence for the production of EM-type ocean island basalts and large volumes of volcaniclastics during the early history of the Manihiki Plateau. Mar Geol 122:181-205

Billen MI, Stock JM (2000) Morphology and origin of the Osbourn Trough. J Geophys Res 105(B6):13481-13489

Clift PD (2005) Sedimentary evidence for moderate mantle temperature anomalies associated with hotspot volcanism. In: Foulger G, Natland JH, Presnall DC, Anderson DL (eds) Plumes, plates and paradigms. Geol Soc Am Spec Pap 388, pp 279-287

Erba E (2004) Calcareous nannofossils and Mesozoic oceanic anoxic events. Mar Micropaleontol 52:85-106

Heezen B, Glass B, Menard H (1966) The Manihiki Plateau. DeepSea Res 13:445-458

Hoernle K, Hauff F, Werner R, Mortimer N (2004) New insights into the origin and evolution of the Cretaceous Hikurangi Plateau. Eos Trans Am Geophys Union 85(41):401

Ingle S, Mahoney JJ, Sato H, Coffin MF, Kimura JI, Hirano N, Nakanishi M (2007) Depleted mantle wedge and sediment fingerprint in unusual basalts from the Manihiki Plateau, central Pacific Ocean. Geology 35:595-598. doi: 10.1130/G23741A.1

Ito G, Clift PD (1998) Subsidence and growth of Pacific Cretaceous Plateaus. Earth Planet Sci Lett 161:85-100

Jenkyns H (1976) Sediments and sedimentary history of the Manihiki Plateau, South Pacific Ocean. Init Rep DSDP 33:873-890

Joseph D, Taylor B, Shor AN, Yamazaki T (1993) The Nova-Canton Trough and the Late Cretaceous evolution of the central Pacific. In the Mesozoic Pacific: geology, tectonics and volcanism. Am Geophys Union Monogr 77:171-185
Kauffman EG (1976) Deep-sea Cretaceous macrofossils: DSDP Site 317A, Manihiki Plateau. Init Rep DSDP 33:503-535

Larson RL, Erba E (1999) Onset of the mid-Cretaceous greenhouse in the Barremian-Aptian: igneous events and the biological, sedimentary, and geochemical responses. Paleoceanography 14:663-678

Larson RL, Pockalny RA, Viso RF, Erba E, Abrams LJ, Luyendyk BP, Stock JM, Clayton RW (2002) Mid-Cretaceous tectonic evolution of the Tongareva triple junction in the southwestern Pacific basin. Geology 30:67-70

Lonsdale P (1997) An incomplete geologic history of the southwest Pacific basin. GSA Abstracts with Programs, vol 29(5), p 25

Mahoney J, Spencer K (1991) Isotopic evidence for the origin of the Manihiki and Ontong Java oceanic plateaus. Earth Planet Sci Lett 104:196-210

Mahoney J, Storey M, Duncan RA, Spencer KJ, Pringle M (1993) Geochemistry and age of the Ontong Java Plateau. In: Pringle MS et al (eds) The Mesozoic Pacific: geology, tectonics, and volcanism. Am Geophys Union Geophys Monogr 77, pp 233261

Mayer LA, Shipley TH, Winterer EL (1986) Equatorial Pacific seismic reflections as indicators of global oceanographic events. Science 233(4765):761-764

Rea DK, Lyle MW (2005) Paleogene calcite compensation depth in the eastern subtropical Pacific: answers and questions. Paleoceanography 20:PA1012. doi: 10.1029/2004PA001064

Sandwell DT, Smith WHF (1997) Marine gravity-anomaly from Geosat and ERS-1 satellite altimetry. J Geophys Res 102:10039_ 10054

Schlanger SO, Winterer EL (1976) Underway geophysical data: Navigation, bathymetry, magnetics, and seismic profiles. Init Rep DSDP 33:655-693

Schlanger S, Jackson E et al (1976) Site 317. Init Rep DSDP 33:161300

Smith WHF, Sandwell DT (1997) Global sea floor topography from satellite altimetry and ship depth soundings. Science 277(5334):1956-1962

Stock JM, Luyendyk BP, Clayton RW et al (1998) Tectonics and structure of the Manihiki Plateau, western Pacific Ocean. Eos Trans Am Geophys Union 79:F870

Sutherland R, Hollis C (2001) Cretaceous demise of the Moa plate and strike-slip motion at the Gondwana margin. Geology 29(3):279-282

Taylor B (2006) The single largest oceanic plateau: Ontong JavaManihiki-Hikurangi. Earth Planet Sci Lett 241(3-4):372-380. doi: 10.1016/j.epsl.2005.11.049

Winterer EL, Lonsdale PF, Mathews JL, Rosendahl BR (1974) Structure and acoustic stratigraphy of the Manihiki Plateau. Deep-Sea Res 21:793-814 